\title{
Application of Sequence Stratigraphy in Depression Lake in Slope Zone, Taking Shenvsi Oilfield as an Example.
}

\author{
Ji Ling, Wang Qingkui \\ (1.Graduate School of PetroChina Research Institute of Petroleum Exploration \& Development,Beijing \\ 100083,China;2. The third production company, Petrochina Dagang oil filed, Cangzhou 061035, China)
}

\begin{abstract}
In order to describe the distribution of the depression in the depression zone, the fault block is better developed. Based on the study of sedimentary microfacies, the reservoir sequence is divided and the distribution range of sand bodies is plotted by using sequence stratigraphy and comprehensive application of seismic, logging, logging and production dynamic data. Through the research on the Shahejie Formation of the Nv 32 fault block in Shenvsi Oilfield, the problem of unclear reservoir is solved and the scientific basis for oilfield development is provided.
\end{abstract}

Keywords: Shenvsioilfield, shore shallow lake facies deposit, bio-limestone, sequence stratigraphy method

\section{Introduction}

Block 32 has an oil area of $1.2 \mathrm{~km}^{3}$ and oil layer for the sand about the geological reserves of $99 \times 10^{4} \mathrm{t}$. There are 7 wells in the block, 6 wells open, only $13.5 \mathrm{t} / \mathrm{d}$ of Nissan oil, $88.5 \%$ of the block water, $0.5 \%$ of the oil recovery rate and $20.5 \%$ of the recovery. The block development is basically in a stagnant state. Can not adapt to the current production situation.In this paper, the continental sequence stratigraphy theory is used to explain the distributions of the sedimentary microfacies in the coastal sedimentary facies. The seismic sequence stratigraphy method is used to determine the sedimentary microfacies range and guide the development of the fault block.

\section{1、 structural features and sedimentary background}

Shenvsi Oilfield is located in the southwest of Huanghua Depression, north of Nanpi Depression, west Cangxian uplift, oil area of 24 square kilometers, the target area Nv 32 block is located in the west of the Shepci Temple oil field, under the control of a Cangdong fault The fault structure is small and the fault distance is small, which is not enough to control the oil and gas distribution.The sedimentary facies of the Kongdian Formation were eroded at the end of the sediments and formed unconformably with the sandy sediments. The sedimentary facies of the sandy and sandy sediments were abundant and sedimentary sandstone or gravel-like sandstones were deposited. During the sedimentation period, the water body is deepened and reaches the largest lake. Observed by the core and logging data, reservoir lithology is mainly sandstone and carbonate rock, from the bedding and stratigraphic structure reflects the strong hydrodynamic, sandstone mainly sand or fine sand and gray green, light gray silt Mudstone interbedded, sandstone uniform size, sorting, grinding round is better. Carbonates are mainly bioclastic limestone. Sandstone has a massive, plate-like, wavy staggered bedding, and mudstone sandstone developed massive and layered bedding, indicating that they are formed under strong wave action. Shallow lake area due to the waves hit the bottom of the lake, underwater oxygen sufficient, and because close to the lake, the river brought nutrients, so a variety of organisms are developed, logging common ostracoda and other biological shell. Shallow lake area is located above the wave base, the wave of strong, more types of bedding. The sedimentary rhythm layer is mainly composed of four parts, the bottom is massive, plate-like, wavy staggered bedding sandstone, siltstone, muddy siltstone, upward into massive, layered silty mudstone, mudstone, Calcareous mudstone, the upper part is massive, layered, wavy staggered bedding, bio-limestone. Accordingly, there will be three kinds of sedimentary microfacies: the biological beach, the lake lake dam, the beach edge.

The microfacies of the biological beach are mainly composed of bioclastic limestone deposits, which are distributed in the shoal area. The single layer has a large thickness and the resistivity is large. The lakeshore sand dam is mainly composed of the mud dams, Thinner, $3-5 \mathrm{~m}$; beach microfacies are mudstone deposited in a quiet lake of shallow lake. The main types of reservoir sedimentary microfacies are biological beach and lake lake dam. The first phase of the sand began to develop fan delta front subfacies, the main lithology of silt, silty sandstone. Dongying group began, the water gradually shallow, for the water back process, the main development of mudstone, mud shale, the end of the erosion, and the formation of the formation of Guantao unconformity.The lithology of the oil well in Shahejie Formation of this fault block is mainly limestone, followed by siltstone. The mudstone of sandy and Dongying groups is widely distributed with gray and green color, followed by gray and dark gray, with red mud shale and a good regional cap rock. 


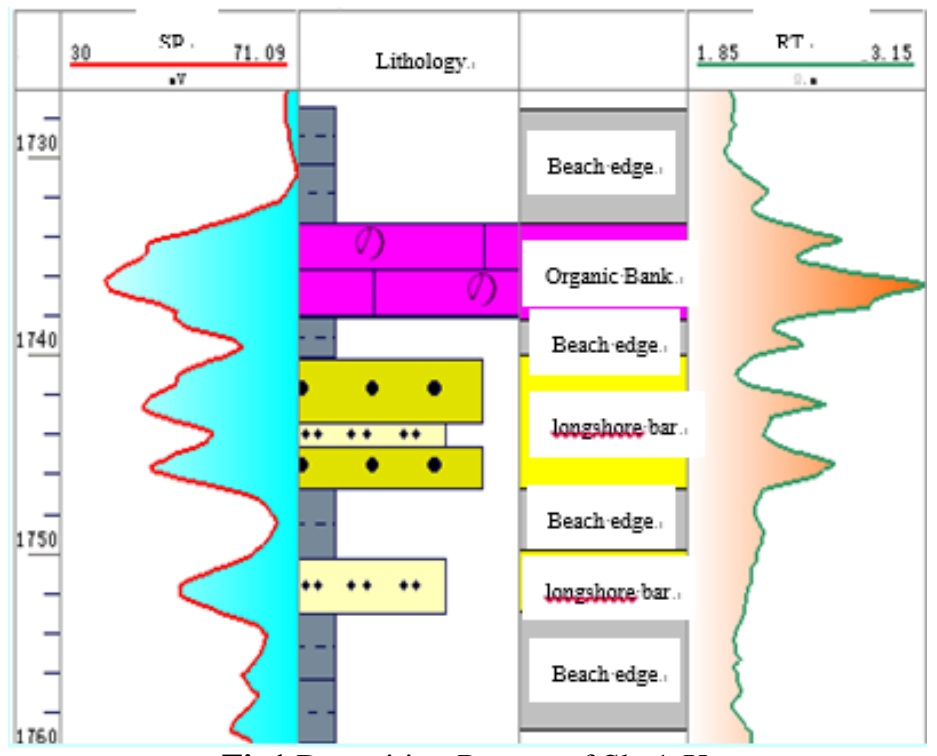

Fig1 Deposition Pattern of Sha1-X

II. Application Of Sequence Stratigraphy

2.1、Classification of target area and stratification of stratigraphy

The key to the application of sequence stratigraphy is the identification of various levels of stratigraphic units, including sequences, quasi-sequence groups, quasi-sequences, layers and layers. In order to carry out the accurate comparison of quasi-sequence and stratigraphy, we must first carry out the study of the three-level sequence boundary and the largest lake. On the basis of establishing the three - level sequence, the quasi - sequence and quasi - sequence are classified, and the interface of quasi - sequence and stratigraphy is finally determined on the basis of quasi-sequence.

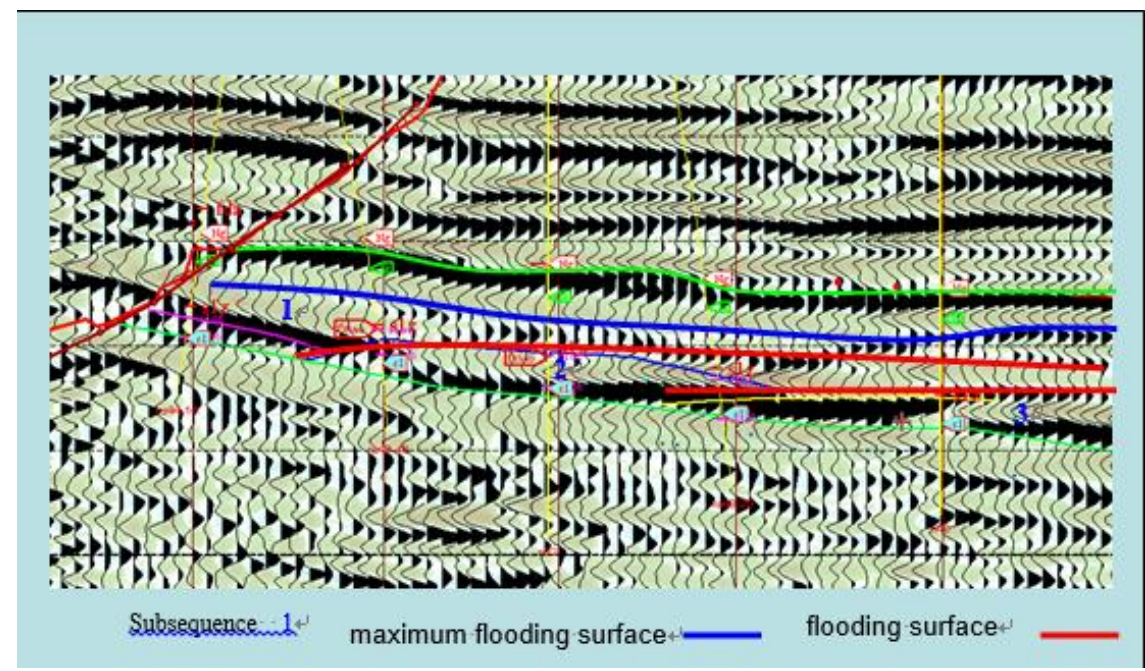

Fig2 Stratigraphic sequence seismic section

Each of the three-stage system tracts is composed of 1-3 system domains. For lacustrine sediments, it can be divided into three systems: high-order system tract, lake-expanding system and low-order system tract. Shenvsi Shahejie Formation is deposited as a typical depression-type lacustrine sediments. The Nv 32 are located on the edge of the sloping slope belt. The main developmental biogenetic shoreline carbonate deposition is developed in the deep lake with deep water oil shale 11 wells), can be classified as endogenous biological lakes. The whole lake basin and the surrounding tectonic activity are relatively weak, the fault is less developed and the terrain is gentle and simple. It is difficult to find a boundary between the low-order system tract and the lake-invaded system tract, and the system area of the depression basin is often divided into the lake, which is similar to the sedimentary facies. Into the system tract and the lake retreat system domain. The seismic profile of the target area is clear on the seismic section, indicating that the sand is a typical lake into the system tract, and the seismic data show that there are three quasi - sequences in the lake. 
2.2、 Sedimentary microfacies distribution and isochronous division of different quasi - sequences

Based on the quasi-sequence division, the sedimentary microfacies are used to divide the reservoir into small time rock units by using the logging data of each well. The correct small layer division and the three-dimensional geological data body established by the reservoir are the reservoir engineers Correctly fit the dynamics of production, the rise in water content and the degree of final recovery.

\subsubsection{Combine seismic data, logging data to correct formation data}

The conventional stratigraphic contrast data is corrected by using the sequence stratigraphic contrast method. According to the original comparison, there is an ups and downs of high and low ups and downs in the seabed at the end of the seismic section, and there is a channeling, and it is found that some of the biological limestone and the sand The rock is on the same seismic reflection axis. After considering the lithology and seismic data, the original comparison data will be corrected, and the upper limestone of the upper part of Shahejie Formation of the Nv 48 and Nv 83 will be placed under the sand.

2.2.2 Based on the upper and lower unconformity as the base, draw the reservoir profile

The results show that the superficial sedimentary phenomena can be combined with the sedimentary facies, and the sedimentary facies of the sedimentary facies is determined by the combination of the seismic data and the lithology data obtained from the logging. Background and Sagittarius Reservoir Description (2006), drawing the reservoir profile 。

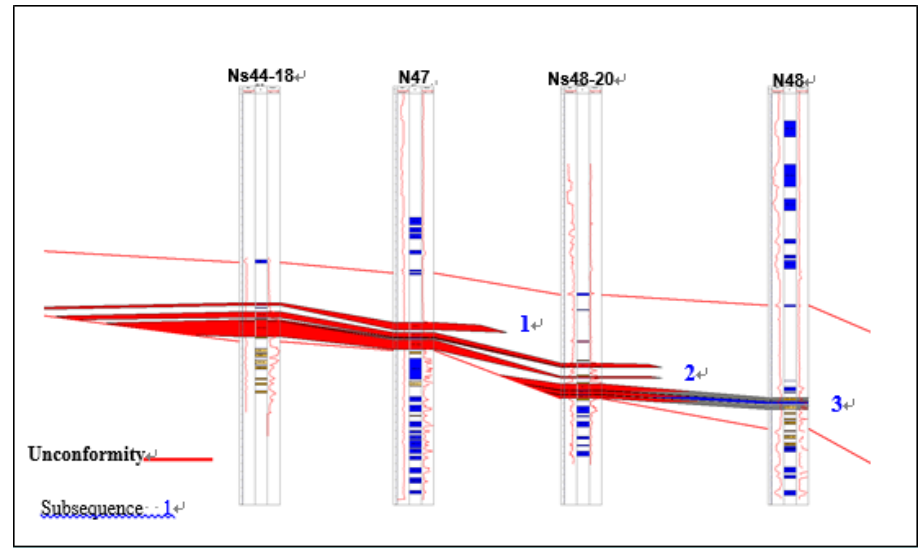

Fig3 Ns44-18-N48 Reservoir profile

2.2.3 Seismic data inversion, the division of sand bodies

Based on the seismic data and the means of production, the sand bodies in the quasi - sequence of the quasi - sequence are delineated and the microstructures of the sand bodies are drawn. According to the means of production and logging data show that No. 1 sand body oil is poor, 2 sand body is rich in oil, 3 sand body is mainly water layer, only with the No. 2 sand body near the boundary of oil and gas show.

2.2.4、Cloth well plan

For the No. 2 sand body for the existing well pattern of the encryption and adjustment, cloth new wells 5, 4 oil 1 water, old wells transferred note 2, were $\mathrm{Nv} 32$ and $\mathrm{Nv}$ 47, is expected to single well Nissan capacity $8 \mathrm{t}$, the new capacity $1.168 \times 104 \mathrm{t}$, improve oil production speed of $1.5 \%$; day water injection $240 \mathrm{~m} 3$, annual water injection capacity of $7.2 \times 104 \mathrm{~m} 3$ 。

\section{Conclusion}

The production of Nv 32 pieces in the Shebomiya Oilfield is complicated and the internal structure is small, and the reservoir lithology is different from the sandstone reservoir in the Cangdong-Nanpi depression. In this fault block, the traditional tectonic interpretation, lithology Contrast methods are biased. After considering the production situation over the years, from the seismic data, the application of sequence stratigraphic ideas combined with the deposition background, emphasizing the lithology in the block in the oil control role, looking for favorable well position, and achieved some results.

\section{Reference}

[1]. Jiang Zaixing. Sedimentology [J]. Petroleum Industry Press, 2003.

[2]. China National Petroleum Corporation、 Key Laboratory of Oil and Gas Reservoirs. Guidelines for Application of Stratigraphic Stratigraphy [J]. Petroleum Industry Press, 2002.

[3]. Zhou Haimin、Dong Yuexia, Geological Rift Basin Sequence Stratigraphy Working Method Atlas [J]. Petroleum Industry Press, 2006. 